\title{
Elephants, safety nets and agrarian culture: understanding human-wildlife conflict and rural livelihoods around Chobe National Park, Botswana
}

\author{
A. Clare Gupta ${ }^{1}$ \\ Yale University, USA
}

\section{Introduction}

This article chronicles the livelihood strategies of smallholder farmers in the village of Naledi ${ }^{2}$ on the edge of Chobe National Park in northern Botswana (Figure 1). Here, the presence of wildlife weighs heavily on peoples' lives. Elephants roam the village and raid arable fields, leaving a wake of destruction as they move freely, protected under conservation law, through an extensive mosaic of designated park land, forest reserves and wildlife management areas that encircle human settlements. For some farmers, crop raiding by 'problem animals' such as elephants is one of the reasons that they have stopped farming their larger arable landholdings, intended for both commercial and subsistence purposes, and now only grow a few fruits and vegetables in small backyard gardens. Others continue to farm, but lament the prevalence of crop raiding by elephants and express little hope that their farming efforts will yield a harvest with commercial or even subsistence value.

Broadly speaking, human-wildlife conflict in Naledi is representative of tensions between the conservation of wildlife and the development of rural agrarian livelihoods in and around protected areas in many parts of the world. A large body of literature specifically addresses the nature of human-wildlife conflict (HWC) and potential solutions (Hill 2000; Inskip and Zimmerman 2009; Campbell-Smith et al. 2012). As this article shows, however, a narrowly circumscribed focus on human-wildlife interactions risks overlooking the way in which the effects of wildlife damage on human welfare, and human responses to wildlife conflict, are mediated by the broader socio-economic, political and environmental context in which those interactions are situated (Quirin and Dixon 2012). In this article I use a political ecology approach to move beyond explication of proximate causes and local forces, and to identify the broader systems that influence the way in which human-wildlife conflict in a given place unfolds. This case study explains how farmers' livelihood strategies in areas of high wildlife disturbance in Naledi are affected by a broader sociopolitical context that includes, but is not restricted to, wildlife conservation policy.

My research questions were shaped by farmer sentiments as described above. For households who have given up farming, what alternative livelihood sources (if any) do they access in order to survive and remain living in the Chobe Enclave? ${ }^{3}$ For those who still plow their fields despite marginal returns, what influences them to continue to farm? These questions guided twelve months of ethnographic research, in which I employed a political ecology framework in order to understand the livelihood decisions of these villagers, and their implications for conservation and development policy.

In the article, I demonstrate how in the case of Naledi, the effects of living near Chobe National Park and its protected wildlife are mediated by a relatively well-functioning welfare state (Bertram 2011) that provisions citizens with both agricultural and non-agricultural support. ${ }^{4}$ This is an unusual and noteworthy finding given the extensive documentation in critical conservation studies of cases in which state-sponsored wildlife conservation impinges upon local people's survival (Ngeta 2011; Schmidt-Soltau 2003). I argue that the availability of financial and physical capital from the state, in the context of a high

\footnotetext{
1 Dr. A. Clare Gupta, SEES Fellow, School of Forestry and Environmental Studies, Yale University, USA. Email: claregupta "at" yale.edu; claregupta "at" gmail.com. Acknowledgements: This research was funded by the National Science Foundation Graduate Research Fellowship and Doctoral Dissertation Improvement Grant; the Social Science Research Council International Research Dissertation Fellowship; the Fulbright Program for U.S. Scholars; the Rocca Fellowship for Pre-Dissertation Research; and Sara's Wish Foundation. The author expresses thanks to L. Fortmann, J. Brashares and fellow lab members for their insightful and thoughtful editing of various drafts of this manuscript as well as to Mr. P. Mbeha, whose field assistance was invaluable and deeply appreciated. This article appears in a JPE Special Section of Eric Wolf Prize papers edited by Casey Walsh.

2 The village name is a pseudonym.

${ }^{3}$ The Chobe Enclave refers to the five villages, including Naledi, that are adjacent to Chobe National Park and the nearby Chobe Forest Reserves.

${ }^{4}$ I am using Bertram's (2011) definition of a welfare state regime as government policies and expenditures that are intended to secure to individuals or groups measurable benefits which those individuals or groups could not secure directly through participation in the market economy, including payment in cash of income transfers (often including part at least of the public sector payroll) and the provision in kind of key basic services, such as health, education and housing.
} 
degree of wild animal disturbance, leads to two divergent livelihood strategies for Naledi residents. For some households, state forms of assistance (entitlements or employment opportunities) augment income to the point that farmers who face high levels of wildlife disturbance can stop farming altogether, which I term the 'abandonment strategy.' 5 Other households choose to continue farming, despite the fact that it is marginal in the area, because agricultural subsidies create incentives for people to continue to farm with low input and low risk, which I refer to as the 'low-level continuation strategy.' These findings raise the question of whether state transfers play a positive or negative role in terms of their contribution to either livelihood development or wildlife conservation in a protected area. On the one hand, certain forms of state assistance provide a much-needed safety net for those who are no longer able to pursue an agricultural livelihood and allow people to remain on their traditional lands. Yet on the other hand, state support in the form of agricultural subsidies can lead to perverse and ineffective outcomes when implemented in places where they work against competing land uses, such as wildlife conservation. In such places, state transfers may prevent abject poverty, but they reinforce a land use pattern (i.e. the close proximity of human activities to wild animals) that exacerbates human-wildlife conflict and hinders effective economic development.

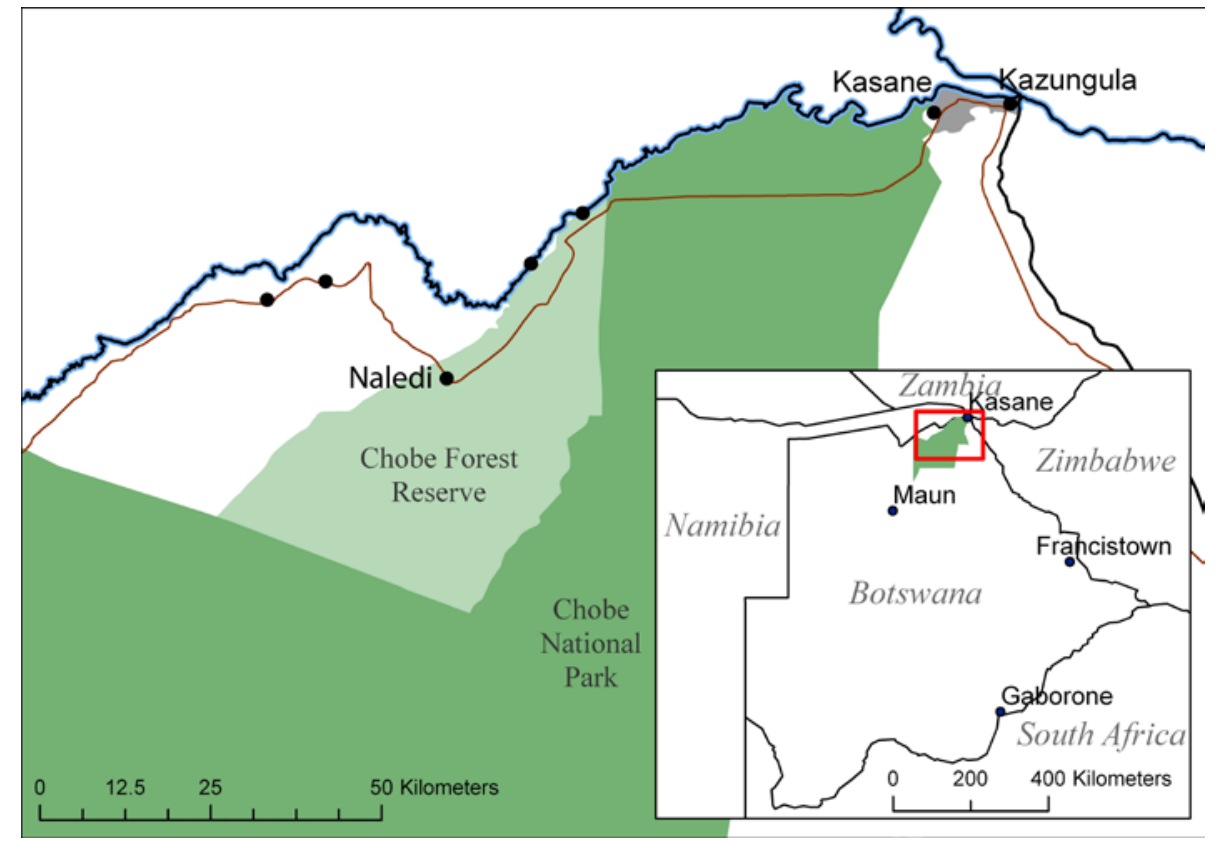

Figure 1. Map of study area in Botswana. Source: author.

This article has six parts. A literature review of political ecology and human-wildlife conflict studies is followed by a description of methodology and then a synthesis of national and regional level data on the Botswana welfare state and the effects of conservation in the Chobe Enclave. This fourth section provides context on the larger national and regional conditions that require understanding in order to make sense of local livelihood dynamics in Naledi. The fifth section then provides description and analysis of primary data on the livelihood strategies that Naledi villagers employ in response to conditions resulting from wildlife conservation policy and the availability of state transfers. Finally, the conclusion addresses implications for analyzing smallholder agriculture in areas subject to wildlife conservation.

\section{Literature review}

Through critical conservation studies, political ecologists have shown how conservation, often driven by powerful global players, can displace local people, dispossess them of their livelihoods and create heightened conflict between various user groups (Geisler and De Sousa 2001; West et al. 2006). As a result

\footnotetext{
${ }^{5}$ Farming in this paper refers to arable farming conducted at the "lands," agricultural holdings of at least (and usually more than) one or two hectares where staples such as maize and sorghum are grown. In Botswana, households are highly mobile, moving between their primary village residence, their cattle post, and their "lands" during different seasons of the year. While households maintain gardens in the backyards of their village residence in order to grow "relish" (e.g. greens to accompany meals), gardening is not usually thought of as "farming" and is considered supplemental to the farming that takes place at the lands, where most of a household's food for consumption and/or sale is traditionally produced.
} 
of exclusionary conservation today, 'conservation refugees' are often forced to turn to wage labor (if they can find it) for survival (Dowie 2009). This kind of process reflects a larger a trend towards what has been termed 'de-agrarianization,' as rural dwellers across the world have been forced diversify their livelihood portfolios away from strictly agricultural-based livelihoods and towards non-agricultural activities (Bryceson 1999; Bernstein et al. 1992). Since the colonial period in sub-Saharan Africa, the livelihoods of rural farmers have been subject to a string of stresses and shocks, including forced labor migration, cash crops, structural adjustment and fluctuating commodity prices. Processes of marginalization, accumulation by dispossession and differentiation that have affected rural communities through the twentieth century have made it increasingly difficult for rural households to make a living based on agricultural activities alone. Land set aside for wildlife and biodiversity conservation is also an important driver of rural agrarian change and can exacerbate the decline of smallholder agriculture that characterizes much of rural Africa today.

Chobe is an example of a place where although people are not physically dispossessed from their farmland, wildlife conservation has negatively impacted the agrarian sector, and in some cases eliminated the ability to farm. This tension between wildlife conservation and agricultural livelihoods is addressed not only by political ecologists concerned with the politics of social justice and nature conservation, but also by conservation scientists and practitioners who recognize human-wildlife conflict to be an obstacle to effective wildlife conservation. Though conservation-oriented studies of HWC are extensive, and provide data on spatial patterns of wildlife disturbances; costs of HWC to farmers; responses and attitudes to HWC; and the efficacy of mitigation techniques, most are focused at a relatively local, or micro, scale (NaughtonTreves et al. 1998; Sitati et al. 2003; Mackenzie and Ahabyona 2012; Granados and Weladji 2012; Davies et al. 2011; Campbell-Smith et al. 2012; Hartter et al. 2011). These studies that pay attention to a protected area and the residents in its immediate proximity are useful for understanding local dynamics, but do not necessarily take into account the broader context that is a critical part of the explanation of why people behave or react in the ways that they do.

In contrast, political ecologists follow a mode of explanation that evaluates the influence of variables acting at a number of scales, each nested within another and situated within a particular historical trajectory. Local decisions (e.g. by individual land managers) are understood to be influenced by past and present regional conditions and policies, which in turn are affected by global politics and economics. At the same time, political ecologists recognize that global-scale phenomena do not have a uniform effect (Robbins 2004). For example, the precise nature of the livelihood strategies that farmers employ in response to declining agricultural opportunities are reflective of global forces, but are also context-specific and contingent on the way in which multi-scalar processes intersect and unfold in a given place at a given time within a particular community of people (Ellis 2000). This research therefore examines all the relevant factors that interact with conservation policy in order to understand human experiences of and responses to wildlife disturbance in Chobe-a first step towards the design of appropriate policies to address HWC.

Within critical conservation studies, key scholars have provided important insights into the way in which conservation policies and projects intersect with ongoing national-level "development" policies (Brockington 2002; Neumann 1998) and political economic regimes (Li 2007). My study builds upon this body of literature by illustrating a case in which rural agricultural development policy and wildlife conservation policy work in opposing directions, as they respectively encourage and discourage local residents' pursuit of agricultural livelihoods. The availability of state welfare support, the lack of available agricultural labor, and the cultural significance of an agrarian identity also converge to influence whether and how households continue to farm or not, as I describe below.

These findings illuminate the way in which household livelihood strategies are shaped by challenges of wildlife disturbance in conjunction with government policies or programs in place in a given conservation area. The Chobe case is noteworthy because it suggests that government social safety nets can both mitigate HWC (by providing livelihood alternatives to farming) and exacerbate tensions over land-use (by encouraging farming in areas of high wildlife disturbance). Detailed study of the local conditions surrounding human-wildlife conflict and an analysis of the broader political economy-in this case the presence of a welfare state-are required in order to understand the unanticipated outcomes of, and responses to, conservation policy.

\section{Methodology}

Data for this study were collected during nine months (2009-2010) in the village of Naledi (population 1,072) in the Chobe Enclave where I conducted participant-observation, five focus group workshops, 25 semi-structured interviews with both village residents, and a household survey (Central Statistics Office 2001). The focus groups and interviews with village residents focused on four major categories: 1) changes in livelihoods and settlement patterns over time 2) migrant behavior 3) household relations/dynamics and 4) reflections on previously collected village-level livelihood data. Approximately thirty additional interviews were conducted with key informants, including village tribal authorities, government officials from various relevant departments at the District and national level, academics, and researchers/consultants involved in agricultural and wildlife policy-making. 
The survey was administered to 49 households (30 percent of total households) by randomly selecting from a list of village plot holders (all residential plots must be registered so the list is relatively comprehensive) from the District Land Board office. The survey was administered to the head of the household, and the spouse of the head of the household if there was one. The survey data used in this article were collected only from the head of the household, as prior comparison of spousal data indicated enough similarity to rely on the household head data as accurately portraying the household. Some 64 percent of respondents were female and 36 percent were male, a relatively high degree of female-headed households. Data on the Chobe District and Botswana state were also collected from the Botswana National Archives, government departmental records, University of Botswana special collections, and other relevant repositories.

\section{Situating Naledi: national and regional context}

\section{Botswana, the welfare state}

Since the discovery and exploitation of diamonds at independence (in 1968) and the subsequent surge forward of the economy, Botswana has strategically used its growth economy and access to donor funds to achieve impressive levels of social service delivery, especially in comparison to most other African countries. Unlike other African countries where subsidies to small-scale farmers have shrunk (Bryceson 1999), Botswana has in fact increased the level of support that it gives to small farmers and publicly stated its intention to promote food sovereignty and reduce its dependence on South African food imports. As a result, the government has rolled out new iterations of subsidized farming programs. In 2002, the Ministry of Agriculture launched the National Masterplan for Arable Agriculture and Dairy Development (NAMPAADD), a broad agricultural development strategy intended to re-structure arable agriculture and dairy development programs that is particularly geared towards the transformation of traditional farms into viable commercial enterprises. For dryland arable agriculture-the most common type of farming amongst rural Batswana ${ }^{6}$ - the major activities are to encourage smallholder farmers to form large units (clusters) of at least 150 hectares, to establish service centers for providing inputs and services at each unit, and to promote the adoption of mechanized farming. These programs have yet to be systematically evaluated and are still in the process of implementation, but thus far, they have had disappointing results for rural agricultural productivity and income generation (Seleka 2004).

The National Strategy for Poverty Reduction (2003) recognizes the importance of broad-based economic growth as a means to promote reduction in poverty but also emphasizes the need for the government to continue to use social safety networks to target the most vulnerable segments of society. In practice, this strategy has resulted in three clusters of targeted interventions: 1) the problem of low productivity (i.e. low returns of labor) is supposed to be addressed through income generation strategies such as microcredit and agricultural assistance; 2) the problem of vulnerability (i.e. insecure returns to labor) is addressed through safety nets such as drought relief food aid and labor-based public works (Ipelegeng); and 3) the problem of dependency (i.e. inability to work) is addressed through old-age pensions and destitute allowances (BIDPA 2001). Although these types of interventions are not fully effective given that poverty still persists in Botswana, their prevalence reflects the degree to which many Botswana citizens, including those in the Chobe Enclave, rely heavily on government assistance to survive. Indeed, as shall be demonstrated, state transfers play an important role in the livelihood portfolios and decision-making patterns of most Chobe Enclave households.

\section{Conservation and agriculture around the Chobe Enclave: Chobe as a wilderness area}

The Chobe District is a primary safari destination due to its abundant wildlife resources and the extensive Chobe-Zambezi River system. A review of the Chobe District Development Plan reveals a conflict of interest between national and district level land-use priorities: setting aside land for wildlife conservation is extremely important to the country of Botswana because of the contribution of wildlifebased tourism to the national economy, and yet, these priorities eclipse the possibility of other types of land-use that might help to diversify the local economy and promote income generation and rural development. ${ }^{7}$ Reacting to criticism for its dependency on mining since political independence, in the last two National Development Plans, Botswana has identified tourism as one of the key sectors that could help diversify the economy (Leechor 2005). Since the success of the tourism industry relies on the sustainability of the nation's wildlife population, the government of Botswana has increasingly developed plans and policies for effective natural resource management and conservation of the country's wilderness areas (i.e.

\footnotetext{
${ }^{6}$ In Setswana, the official language of Botswana, one person from Botswana is referred to as a "Motswana," multiple people are referred to as "Batswana," and the adjective used to describe parts of the national culture is "Setswana" (e.g. a "Setswana way of life").

${ }^{7}$ Tourism accounted for an estimated share of 10 percent of GDP (or about 16\% of non-mining GDP) in 2007 (The Voice 2008)
} 
the northern portion of the country). Therefore, as the most recent Chobe District Development Plan (2003) plainly states, there is an "acute shortage of land" in the District due to the fact that about 80 percent of it is devoted to conservation of wildlife and forest resources, leaving very little room for settlement expansion and other economic activities. The Chobe Enclave where Naledi is located is sandwiched between the Chobe Forest Reserve and Chobe National Park (11,000 km²), established in 1968 (Figure 1).

\section{Conservation and agriculture around the Chobe Enclave: agriculture in the Enclave}

People in the Chobe Enclave (roughly 4,400 residents) have historically engaged in arable agriculture as a livelihood. Climatic and soil conditions in are much more favorable for arable agriculture than the rest of Botswana, because of higher than average rainfall and the relatively fertile soils in the regularly flooded plains (where floodplain mopalo farming takes place). Despite these advantages, arable agriculture remains a risky endeavor because of erratic rainfall with periodic droughts and regular flooding of arable lands that cause frequent crop failures. Under these variable natural conditions, agricultural production is characterized by low inputs of capital and labor (Barnhoorn et al. 1994), and most farmers prefer to have both rain-fed dryland and mopalo farms in order to spread risk and increase production potential. Historically, if the mopalos were either too dry or flooded, the rainfed fields offered an alternative, unless they were also affected by drought. As a result of these constraints, the cultivated area, yield levels and total agricultural production varies considerably from year to year and among households, making it impossible to estimate an average yearly yield (Barnhoorn et al. 1994). At times, the Chobe Enclave has produced enough grains for commercial sale. ${ }^{8}$ Yet today, as in the past, in years without good rainfall or with flooding, households are unable to produce enough food for themselves and the Enclave receives major inflows of maize meal. Indeed, from 2007/08 to 2009/10, Naledi and its neighboring two villages in the southern Enclave sold no crops to the Botswana Agricultural Marketing Board.

\section{Wildlife stresses on agricultural livelihoods}

For farmers in Chobe, the government's prioritization of wildlife conservation means further marginalization of their already risky agriculture-based livelihoods, with few benefits in exchange. Landuse constraints along with poor performance of the agricultural sector, due in part to livestock predation and crop damage by wildlife, help to explain why economic activities in the Enclave have been characterized as "non-existent" (DDP 2003), and why increased agricultural productivity, one of the goals of the National Development Plan and the Rural Development Policy (2002), has not materialized.

Most notably, crop destruction by wild elephants is increasingly a problem as Botswana's elephant population has increased sixteen-fold over the past fifty years to an estimated 133,829 individuals, with 70 to 80 percent of the population living outside of the National Park (World Bank 2009). Data from the Department of Wildlife and National Parks on 'Problem Animal Control' show that the number of elephant conflict reports for Naledi rose dramatically over a 10 year period-nine reports were filed in 1995 and consistently increased through 2004, when 38 reports were filed (K. Alexander, unpublished data). ${ }^{9}$ My research shows that state-led zoning of land for wildlife and the associated increase in wildlife that freely raid crops have created new adverse conditions that arguably outweigh any of the weather and soil-related benefits that exist for Chobe farmers.

Like crops, livestock are also subject to predation by wild animals. Naledi residents express great frustration at the fact that current conservation law forbids them from killing problem animals like elephants. Residents agree that as a result, wildlife has become increasingly aggressive and less fearful of humans, and that today traditional scare tactics such as beating drums and tin cans no longer deter elephants. Villagers cannot expand communal grazing lands without encroaching on the reserves. Nor can they sell their livestock to the highly lucrative (and subsidized) European Union (EU) market as do farmers in the rest of Botswana. EU regulations that require beef imports to be hoof-and-mouth-disease free make Chobe livestock ineligible. Believed to be transmitted from buffalo to cattle, Batswana officials have designed elaborate fences which divide the country into export zones (mainly wildlife free areas in the south) and non-export zones (mainly wildlife-rich areas in the north) to separate livestock from wildlife and prevent disease transmission. Chobe's rich wildlife populations land it squarely in a non-export zone. They are thus not accepted by the Botswana Meat Commission, the entity responsible for managing EU regulation compliance.

\footnotetext{
${ }^{8}$ For example, in the 1940s, the Enclave was Botswana's most productive agricultural area, exporting large surpluses of maize (maize and sorghum are the staple grains in this region). Disastrous floods in the 1950s led to several decades of depression. By the 1980s the agricultural economy had improved and in favorable years (with good rains and flood recession) the Chobe Enclave became a net exporter of grains (MacDonald 1989). These grains were (and today still are) purchased by the Botswana Agricultural Marketing Board (BAMB) (current price: approximately \$275 per tonne of maize). For example in 1985 BAMB purchased 86 metric tonnes of maize grain and then 503 tonnes in 1986 from the Chobe Enclave (Central Statistics Office 1987). These two years followed almost a decade in which the Enclave sold no grain at all to BAMB, and in which the proportion of maize harvested was between nine and 100 percent.

${ }^{9}$ These numbers represent underestimates of elephant conflicts given that most incidents go unreported.
} 
Attributing the difficulties of small farmers in Chobe solely to wildlife and conservation policy would overlook the multiple historical and geographical reasons for agricultural decline more generally in Botswana over the past century. The prevalent low input-low output farming approach is a response to both the risks involved in farming in an ecologically marginal landscape, and labor constraints (BIDPA 2001). ${ }^{10}$ Historically, the migration of men out of the villages to the South African mines in the early 1900s reduced the amount of available labor for full-time farming and resulted in lower yields and a switch to less labor intensive crops (Hartland-Thunberg 1978; Schapera 1966). Since then, the growth of Botswana's urban economy and the unattractiveness of rural livelihoods (i.e. an un-remunerative agricultural economy and lack of employment opportunities) have resulted in continued out-migration from rural areas (Gwebu 2004). In Chobe, residents from the Enclave move to the District capital of Kasane to work in the tourism industry and growing public administration sector (Kemmonye 2009). This demographic trend further constrains the ability of those who remain in the Enclave to practice agriculture (BIDPA 2001; Gupta forthcoming). Yet wildlife, and especially elephants, have nonetheless made farming even more challenging in an already ecologically and economically marginal landscape. Thus, although the decline of agriculture is widespread within Botswana and not unique to Chobe, conservation in Chobe has greatly reduced the role that agriculture can play as a safety net for the rural poor and as a buffer against external shocks to a rural household's livelihood portfolio (BIDPA 2001). Despite conservation-development programs designed to mitigate costs incurred by local residents from HWC, providing local communities with benefits from wildlife have had limited success. Attempts at Community Based Natural Resource Management (CBNRM) which rely on principles of devolved management, and improved wildlife-based livelihood options to buffer against wildlife-related damages and dangers community participation and direct economic gain, have failed to fully meet their goals (Rozemeijer 2009).

\section{Livelihood strategies in Naledi}

Given that in most of the Chobe Enclave neither agriculture nor wildlife harvesting remains a primary livelihood activity and that CBNRM has not provided a viable livelihood alternative for local residents, the question then arises, what are the livelihood strategies of local residents and how have they been mediated by national political economic and local environmental conditions? How are smallholder farmers responding to the decline of agricultural livelihood opportunities that results from living in close proximity to a protected area and protected wildlife? More specifically, how have some farmers been able to give up farming as part of their livelihoods and why have others continued to farm in the face of increasing wildlife depredation?

In this section I will present data that show that most households in the Chobe Enclave rely heavily on external channels of support-namely, state transfers from the government and remittances from family members working outside the Enclave. While the role of remittances in structuring livelihoods and kinship relations in Chobe Enclave is detailed elsewhere (Gupta forthcoming), here I explain the contribution of state transfers to household incomes and how these transfers influence the ways in which villagers strategically engage in certain types of livelihood activities.

\section{The role of state transfers}

While the government of Botswana provides a large percentage of income to many households in Botswana in general, in northern Botswana people are especially reliant on state-provisioned safety nets to survive. A 1992 survey in the Enclave found that 52.4 percent of households reported receiving at least one form of government assistance (SIAPAC 1992). A 2001 survey revealed that government transfers make up 55 percent of the total income from all livelihood activities in northern Botswana ${ }^{11}$ (BIDPA 2001). In my 2010 survey of Naledi, 23.4 percent of households said that their main source of income was government assistance. ${ }^{12}$ On average government assistance comprised a quarter of the livelihood portfolio of a typical Naledi household (Table 1). ${ }^{13}$ Residents of Naledi recognize that government assistance is widespread within the village and of considerable importance to households. In focus group discussions during which I presented data from the prior 2001 survey showing a high reliance on government support

\footnotetext{
${ }^{10}$ The reasons for the decline of agriculture in terms of its productivity and contribution to livelihoods also include decreased and/or less reliable rainfall (as reported by local Chobe farmers); and rising income inequalities and decreased access to the means of production (i.e. livestock for draught power) for many households (Barnhoorn et al. 1994; BIDPA 2001).

${ }^{11}$ In this survey, "Northern" referred to Chobe and Ngamiland districts. Disaggregated data for Chobe district alone are not available, but the data are still useful because they show the difference between reliance on government agricultural support in Naledi (and the northern region of which it is a part) compared to the rest of Botswana.

12 The specific forms mentioned included pension money, other social welfare entitlements and money from Ipelegeng, the government sponsored day labor program.

${ }^{13}$ In comparison, remittances, another external source of income, are estimated to contribute 20\% to the average Chobe Enclave household livelihood portfolio.
} 
in northern Botswana, all participants agreed that this finding was correct given the lack of employment or agricultural opportunities in the village.

\begin{tabular}{|c|c|}
\hline \multirow{4}{*}{$\begin{array}{l}\text { NORTHERN } \\
\text { BOTSWANA }\end{array}$} & $\mathbf{5 5 \%}$ of HH income from govt. transfers \\
\hline & 72.4\% of HH get access to agricultural inputs through govt. support programs \\
\hline & 71.1\% of HH get direct access to food through govt. support programs \\
\hline & $\mathbf{1 3 . 8 \%}$ of HH report govt. agricultural support to be not important \\
\hline $\begin{array}{l}\text { CHOBE } \\
\text { ENCLAVE }\end{array}$ & $\mathbf{5 2 . 4 \%}$ of HH receive at least one form of government assistance \\
\hline \multirow{3}{*}{ NALEDI } & $\mathbf{2 5 \%}$ of HH income from govt. transfers \\
\hline & $\mathbf{2 3 . 4 \%}$ of HH cite government assistance as main source of income \\
\hline & $\mathbf{1 6 . 8 \%}$ of village population receive direct state support (i.e. entitlements) \\
\hline
\end{tabular}

Table 1: Dependence on government assistance in Naledi village and broader region (sources: BIDPA 2001; SIAPAC 1992; primary survey data)

Chobe residents access government transfers through three main categories of support programs described in the section above. In Chobe, the primary programs in place to boost livelihood productivity are the national-level Citizen Entrepreneurial Development Agency (CEDA) that gives loans to Batswana wishing to start a small business, and the Integrated Support Program for Arable Agriculture Development (ISPAAD). ISPAAD distributes seeds and fertilizer to farmers and provides them with farming implements. ISPAAD not only provides farming inputs and technical assistance but also eliminates the need for household farm labor during the plowing season by providing farmers with tractors and government-paid tractor drivers. ${ }^{15}$ Through ISPAAD, the government spends 700 pula (equal to US\$106 at the time of writing) per hectare during the plowing season to prepare the soil, plow the fields and plant seeds for farmers in the Chobe Enclave. Farmers who do not use the ISPAAD tractor and plow using their own livestock are given money equivalent to the amount that the government would have spent to plow for them (Mazila, personal communication, 2010).

The government of Botswana's labor-based public works program, Ipelegeng, provides a source of (at least temporary) employment and income to many Chobe Enclave residents. Records from the Chobe District Council show that in the year 2008-09, there were 284 beneficiaries of Ipelegeng in Naledi, which represents roughly a quarter of the population of the village $(1,072)$, or over one person per household working for Ipelegeng. In interviews and focus group discussions, participants agreed that more than half of households in their village rely on Ipelegeng as an important source of income. Villagers emphasized the importance of Ipelegeng in providing temporary work especially to youth in the face of a lack of farming and formal employment opportunities.

While government-subsidized farming and government job creation target disadvantaged yet ablebodied individuals, the government also provides welfare to those who are unable to work through a number of social welfare programs such as the old-age pension scheme, World War II veteran grants, food packages for the very poor, supplementary feeding programs for vulnerable groups and primary school children, provision of food, clothing, education and protection to orphans, and assistance to the terminally ill through home-based care (Seleka et al. 2007). These social safety net (SSN) programs are particularly prevalent in Chobe: 71.1 percent of surveyed households in northern Botswana said that government support programs provided them with direct access to food in comparison to the national average of 19.6 percent (BIDPA 2001). The Chobe District Council (2010) records show that for Naledi, almost twenty percent (16.8\%) of the population is a direct recipient of some form of direct state welfare support, not including the other indirect support programs through which residents can access state resources (Table 1). ${ }^{16}$ Clearly, these programs make a difference to people's survival, and to their household productive

\footnotetext{
${ }^{14}$ Further, one man born and raised in Naledi and now living in the capital, Gaborone, cited the decline of the mafisa system as the reason for the high degree of reliance on government welfare. Under the mafisa system in the past, cattle were lent or loaned in trust from cattle-owners to poorer people, in return for tribute, services, and allegiance. This system promulgated patron-client relations but also created a safety net for otherwise destitute households by providing them with access to cattle (Schapera 1966). With the decline of this cultural institution, the state has had to provide alternative types of safety nets to its poorest citizens.

${ }^{15}$ While the government ostensibly provides tractors to all farmers in the Enclave, most farmers complain that there is always a long line to access these tractors, which results in some households plowing late in the season and missing the opportunity to plow at the optimal time when the first rains arrive.

${ }^{16}$ In Naledi there are about 70 beneficiaries of the Old Age Pension Scheme (which provides anyone over the age of 65 with 220 pula a month), 34 beneficiaries of the Destitute Persons Program (which provides destitutes with 81 pula per
} 
strategies, as they allow people to remain living in a place where without them their life would be untenable.

State transfers in Chobe mean that villagers can either afford to stop farming their fields altogether because state forms of assistance contribute to household income directly through entitlements and/or indirectly through employment opportunities, or they continue to farm at least minimally with low input and low risk because of government-sponsored agricultural subsidies. In this latter situation, the continuation of farming in many cases means plowing, but not necessarily spending the time or money to tend to or protect one's fields in order to ensure a harvest. ${ }^{17}$

\section{The cessation of farming: the abandonment strategy}

Evidence suggests that the percentage of households in Naledi who are farming their fields has decreased over the past three decades. In 2010, 61.1 percent of surveyed households from Naledi with some type of arable land, either mopalo or dryland fields or both, reported that they did not plow in the 2009-10 agricultural season. These numbers contrast with a 1984 agricultural survey of Naledi, which found that approximately 11percent of households in Naledi with some type of arable land did not plow that year (Tsimako 1984). In other words, while in 1984 roughly 90 percent of Naledi households with land were plowing, in 2010 only about $40 \%$ percent of those with land were plowing (Table 2). This trend was confirmed by the Principal Technical Officer at the local Land Board, who reported that most arable fields around Naledi are currently unutilized, as evidenced by the fact that lack of maintenance of fields maks it hard for the Land Board to determine boundary lines between fields (L. Kebaitse, personal communication, April $7^{\text {th }}$, 2011). It was further confirmed by the comments of most of my interviewees, who, when asked about changes in the Enclave they had observed over their lifetime, reported that today people buy food from the stores and agriculture plays a much smaller role in village life. Not surprisingly then, the 2010 survey we conducted showed that both the sale and consumption of crops contribute on average only 7.3 percent to a household's survival in Naledi (4\% in the dry season and $10.5 \%$ in the wet season). ${ }^{18}$ As one elderly lady commented during a 2009 focus group; "in the past, we used to plow and harvest and eat what they get from fields... we didn't buy stuff like rice...but today we are suffering; we have to buy food and we are not working."

\begin{tabular}{|l|c|c|}
\hline & 1984 & 2010 \\
\hline $\begin{array}{l}\text { Households plowing (either mopalo or dryland or } \\
\text { both) }\end{array}$ & $\begin{array}{l}88.57 \%- \\
89.74 \%{ }^{19}\end{array}$ & $61.11 \%$ \\
\hline Households with fields not plowing & $10.26 \%-11.43 \%$ & $38.89 \%$ \\
\hline
\end{tabular}

Table 2: Recorded levels of plowing over three decades for Naledi study site (sources: Tsimako 1984; primary survey data)

\section{Elephant disturbance discourages farming}

While it is difficult to prove that elephants are the singular reason for a decrease in arable agricultural activities in Naledi in comparison to a few decades ago, several pieces of evidence together suggest they and other crop raiders are at least one very important reason. Farmers in Naledi whom I interviewed individually reported that they and many of their neighbors no longer plant crops in their fields due to pressure from wildlife and in particular, fear of elephants raiding crops. Focus group discussions confirmed this finding, as residents of Naledi repeatedly emphasized that wild animals were destroying crops and making farming an increasingly unviable activity. As one young man explained;

month and a food basket), 35 beneficiaries of the Orphans Care Program, 34 beneficiaries of the Primary School Feeding Program and about 7 beneficiaries of the Home-Based Care program.

${ }^{17}$ An analysis of the qualities that characterize the types of households that choose to utilize the available agricultural subsidies to continue plowing versus those that give up farming altogether is beyond the scope of this study and warrants further research.

18 This percentage refers only to crops harvested from the fields, and does not include fruits and vegetables more commonly grown in a household's backyard garden. Follow-up research in the spring of 2011 suggested that an increasing number of households are growing more crops than usual in their backyard gardens in lieu of planting at their fields. The degree to which these garden crops contribute to a household's livelihood portfolio and in particular food security warrants further research.

19 These figures represent estimates because the Tsimako survey data regarding land tenure in the Enclave is only provided at the aggregate level, showing that four households of all five Enclave villages had neither mopalo nor dryland fields. Tsimako surveyed 39 households in Naledi so the number of households in Naledi with some form of arable land can be estimated to be somewhere between 35 and 39 households. Her study found that four households in Naledi were not plowing, allowing for an estimation of the percentage of Naledi households with fields who are not plowing them. 
"...when I was growing, plowing was main fact of life, so when wild animals attacked we killed them, but now if you kill an elephant you have to answer for that...we plow but get nothing...tomorrow you go early to the fields but find nothing because of elephants." 20

Another female resident stated matter-of-factly; "the number of wild animals has increased so people don't want to plow because when they plow animals destroy their crops." Other studies in the Enclave have also found a similar sentiment amongst Naledi villagers. For example, in a participatory community action plan Naledi residents listed "increase in wildlife numbers" and "food problems caused by wildlife menace" as two of their top ten problems (USAID 1994).

Frustration towards elephants that destroy crops has, at least in part, caused many Naledi residents to give up plowing their fields. This is further confirmed by results from my preliminary 2008 survey of Naledi, in which only 48 percent of households with arable fields reported that they had planted crops that year. Seventy-five percent of the 2008 survey respondents who did not plow said they did not farm because of concerns about potential elephant damage. Of out-migrants from Naledi interviewed in 2011, 55.2 percent cited elephants as the cause of agricultural decline in their home village ( $\mathrm{N}=67$ unstructured interviews; no prompt regarding elephants or agriculture). These findings are corroborated by the aforementioned evidence from reports that human-elephant conflict incidents (in the form of crop damage) are rising in Naledi (K. Alexander, unpublished data). This increase in HWC incidents is not surprising given ecological data showing that wildlife movement corridors run directly through Naledi and the two adjacent Enclave villages, which together comprise the southern Enclave (Chobe Enclave Management Plan 2003). Elephants travel from the Forest Reserve to the Chobe river for water, especially during the dry season, and cut directly through the escarpment upon which Naledi is situated.

A comparison of the Northern and Southern parts of the Enclave in terms of plowing intensity and wildlife movement also indicates that wildlife, and/or fear of wildlife, discourages Naledi villagers from farming. Table 3 shows that over the past three years, the percentage of available arable land that is plowed has been consistently lower in the southern Enclave (the three villages including Naledi that are situated in a wildlife corridor) than in the northern Enclave (comprised of two villages away from wildlife corridors). For example, in 2010/11, the southern Enclave plowed 5.4 percent of their available land while the northern Enclave plowed 19 percent (ISPAAD 2011). In the three agricultural seasons from 2007/08 to 2009/10, the southern Enclave sold no surplus grain to the Botswana Agricultural Marketing Board while the northern Enclave sold maize during two of these seasons (and did not have excess maize in 2009/10 due to extensive flooding) (BAMB District officer, interview, May 14 $\left.{ }^{\text {th }} 2010\right)$. Given that apart from elephant movement patterns the Northern and Southern Enclave face similar challenges to farming (Barnhoorn et al. 1994), these data suggest that there is an inverse relationship between wildlife disturbance and intensity of farming.

\section{State transfers provide an alternative livelihood source}

Wildlife populations and their movements do not, however, entirely explain the observed abandonment strategy. Botswana's broader political economy clearly matters too. David Jones proposed in the 1980s that transfers and remittances explained why the unemployed in Botswana appear to prefer nonemployment to arable agriculture and why they retain unutilized labor time that they cannot, or will not, devote to the arable sector. He argued that the network of transfers and remittances from those working in other sectors of the economy (e.g. mining, livestock) form a safety net that is "sufficient to permit many people who have no other source of profitable employment to reject the low and risky returns of employment or self-employment in arable agriculture or to indulge in arable agriculture only on a minimum-effort-maximum-return-to-labor basis" (Jones 1981). This thesis is rooted in the fact that ruralurban linkages in Botswana are very strong and many rural dwellers depend heavily upon remittances to survive (Barnhoorn et al. 1994; Lesetedi 2003). This is certainly true in the Chobe Enclave where many men and women leave, due to the poor wage earning opportunities, to seek employment in the nearby town of Kasane or further away. ${ }^{21}$

\footnotetext{
${ }^{20}$ In Setswana, the words for "plowing" and "farming" are used interchangeably. When an interviewee speaks in English, he or she also uses the word "plowing" interchangeably with the word "farming."

${ }^{21}$ My primary research found that that 79 percent of households in Naledi have a family member living outside the village ( $\mathrm{N}=47)$ and 50 percent of these migrants were reported to be sending remittances back to the village.
} 


\begin{tabular}{|c|c|c|}
\hline 2010/11 season: & Hectares plowed & Percent of arable land plowed ${ }^{22}$ \\
\hline Southern Enclave & 269.49 & 5.39 \\
\hline Northern Enclave & 951.08 & 19.02 \\
\hline Total Enclave & 1220.57 & 12.21 \\
\hline \multicolumn{3}{|c|}{ 2009/10 season: } \\
\hline Southern Enclave & 42.88 & 0.86 \\
\hline Northern Enclave & 483.90 & 9.68 \\
\hline Total Enclave & 526.78 & 5.27 \\
\hline \multicolumn{3}{|c|}{ 2008/09 season: } \\
\hline Southern Enclave & 231.51 & 4.63 \\
\hline Northern Enclave & 952.38 & 19.05 \\
\hline Total Enclave & 1183.89 & 11.84 \\
\hline
\end{tabular}

Table 3: Percent of arable land plowed for Southern Enclave (includes Naledi) and Northern Enclave over past three years.

While in Jones's analysis the network of transfers was based on kinship (from employed individuals to unemployed relatives or neighbors) rather than state support, his larger point is still salient and helps explain the livelihood strategies present in Chobe today. Risky returns from agriculture in part explain why historically farmers devoted minimal resources to their agricultural activities, and have been hesitant to adopt technology or infrastructure (e.g. fencing, irrigation) that requires capital investment (MacDonald 1989). As returns become even lower, some households are deciding that even low-input farming is no longer worth the effort and make the choice to stop farming altogether. Interview and focus group participants in Naledi in 2010-11 expressed this decision-making rationale to me numerous times. The chief of Naledi himself explained; "people are slowly getting out of plowing because they realize that they waste time and energy to plow and after that elephants come and sweep up everything, so people are reluctant now [to farm]" (personal communication, April $1^{\text {st }}, 2011$ ). The risk of losing crops to elephants may be only the latest of many challenges to farming in Naledi, but it is enough to push many farmers to a point of giving up entirely. However, what interviewees did not explicitly say to me is that access to alternate sources of income provides them with the option to make this kind of decision. ${ }^{23}$ Yet it is the combination of remittances from family members working outside the Enclave and state transfers that structures livelihood strategies in Chobe and allows some residents to stop farming their fields in the face of increasingly adverse ecological conditions such as increased elephant disturbance and erratic rainfall. ${ }^{24}$ In contrast, farmers in other countries with few other livelihood options are forced to continue farming on marginal lands (Boafo 2004; Sitati 2003) in what frequently becomes a reinforcing cycle of ecological and economic marginalization (Blaikie and Brookfield 1987; Watts 1983).

\section{The continuation of low level 'farming'}

Government agricultural subsidies encourage 'risk-free' plowing

Farming is heavily subsidized for Chobe Enclave households. A 2001 study found that only 13.8 percent of Northern households (comprised of Chobe and one other district) stated that government

\footnotetext{
${ }^{22}$ Percent calculated based on data from Polet (1988) that estimates 10,000 hectares of land to be claimed by Enclave farmers for arable purposes, divided into 5,000 hectares estimated to be subject to individual claims of the two villages in the Northern Enclave and 5,000 hectares subject to claims from Southern Enclave households.

${ }^{23}$ Although on occasion elders would blame job opportunities with Ipelegeng for the younger generation's lack of interest in farming. As one elder focus group participant said, "Ipelegeng is the thing which has made young people abandon plowing."

${ }^{24}$ Whether villagers' reports of increased elephant damage and decreased rainfall are supported by empirical data, is less relevant than the fact that they have the ability to choose to discontinue farming in response to what they perceive to be challenges to productive farming. An examination of the basis of this general perception would warrant a separate study, though Department of Wildlife data does show that elephant populations have increased along with the number of problem animal control reports filed (World Bank 2009).
} 
programmatic support for agricultural production was not an important source of income. ${ }^{25}$ This percentage sharply contrasts to the national average of 70.5 percent of respondents who stated such support was not important (BIDPA 2001). Similarly, 72.4 percent of surveyed households in northern Botswana said that government support programs provided them with access to agricultural inputs in comparison to the national average of 40.5percent (Table 1 ).

According to the Department of Agriculture (2011) records, ISPAAD expenses in 2010/11 in Chobe District totaled $1,642,509$ pula (roughly US\$250,000), with 457,032 pula $(U S \$ 69,500$ ) still owed to farmers. ${ }^{26}$ This expenditure mainly covered payments for hectares plowed but also included expenditure for field extension agents and seeds. The 2010/11 records also show that about half of Naledi households (102/ 200) receive ISPAAD support. In the context of data from my 2008 and 2010 surveys suggesting that somewhere between a third and a half of households (70 to 100 households) are farming their fields, these records indicate that farming is heavily subsidized for the households that decide to farm. This conclusion is supported by agricultural extension agents working in the Chobe Enclave who reported that all farmers who have farmed their fields in the past few years have received support from ISPAAD.

Government agricultural assistance allows Chobe residents who wish to continue farming to do so with minimal inputs of their own, and thus with minimal risk. In fact, the local office of Crop Production reports that the number of individuals plowing and planting their fields has increased in the Chobe Enclave since the introduction of ISPAAD in 2009, because farmers who formerly had given up on farming have now chosen to take advantage of the capital and labor provided through the program (F. Makete, personal communication, April $5^{\text {th }}$, 2011). This creates a situation in which agricultural activities are performed under conditions that without the presence of state subsidies would discourage most risk-adverse households from participating. However, ISPAAD only provides assistance with the initial stages of plowing and planting. It does not help farmers with the increasingly necessary and time-consuming activity of protecting crops from wild animals. As a result, while the number of farmers plowing their fields in Naledi has increased since the introduction of ISPAAD (from 231 farmers in 2006/7 to 682 farmers in 2010/11), production levels have not increased (Mazila, personal communication, April $4^{\text {th }}$, 2011).

The minimal input required by households to plow and plant crops under the ISPAAD program means that people have incentive to cultivate (though not necessarily tend to) their fields, because they have little to lose. At best, they gain a modest harvest that contributes to food security; at worst, their fields yield nothing but they suffer minimal personal expense for the opportunity to potentially gain an additional livelihood stream. Even when the ISPAAD tractor arrives too late in the plowing season, some farmers still choose to participate in ISPAAD-assisted farming because such participation is at no cost to their household. ${ }^{27}$ As one focus group participant explained; "some people do plowing knowing it's too late [in the season] just because the government is giving them free seeds." Another interviewee added; "some people plow because they believe maybe at the end of the day they will get something." This belief is bolstered by the government, which people repeatedly mentioned is encouraging villagers to farm to combat national poverty and food insecurity. ${ }^{28}$ Government agricultural programs provide hope, and incentivize villagers to continue farming because many believe, as one woman stated, that "the government is giving programs which might work [to improve farming] like chili pepper." ${ }^{29}$ When I asked a youth focus group directly whether people would continue to farm without ISPAAD all but one of the participants answered no. ${ }^{30}$ One of the young men explained that part of the reason they continue to plow is because they receive government assistance-"we continue [to farm] because of tradition and because the government recognizes that some [villagers] do farming and that we have to be taken care of."

\section{Cash for farming: financial motivation to participate in state-sponsored agricultural programs}

Evidence also suggests that households and individuals are incentivized to plow their fields because of the access to financial capital from the state that participation in farming provides, regardless of the likelihood agricultural failure. For example, a number of youth interviewees expressed interest in applying

\footnotetext{
${ }^{25}$ In this survey, "income" included the value to the household of its own production.

${ }^{26}$ Records show that the government spent 648,6333 pula (roughly \$US 100,000) on assistance to farmers in the Chobe district in 2008/09 and 276,080 pula (US\$42,000) in the first half of 2009/10. Local officers from the Department of Agriculture explain that the increase in expenditure over the past few years is due to increased participation in the ISPAAD program (Pologolo, personal communication, April $7^{\text {th }}, 2011$ ).

${ }^{27}$ In Botswana, dryland farmers plant crops at the first rainfall (usually around October) in order to take advantage of the peak soil and weather conditions. However villagers have to wait their turn to use the ISPAAD tractor and so some farmers do not have access to the tractor until well past the first rains of the season.

${ }^{28}$ As one elderly lady commented, "the government is encouraging them [villagers] to eradicate poverty so the government is giving us a hand [to farm]."

${ }^{29}$ The Department of Wildlife has created demonstration plots in each of the Enclave villages to test the effectiveness of planting chili peppers as a deterrent to elephants; however, this program has been slow to develop and is currently only in its trial stages.

${ }^{30}$ This focus group included twelve participants ranging in age from eighteen to twenty-five.
} 
for money from the Young Farmer's Fund in order to start small projects. However, several key informants reported to me that the few youth recipients of the Young Farmer's Fund had either used the money for purposes other than farming or had devoted minimal effort to their proposed farming endeavors. ${ }^{31}$ Similarly, the agricultural officer for Chobe explained to me that the 'less serious' farmers in Chobe who had previously given up on farming but were now plowing their fields under ISPAAD viewed the plowing and planting of their fields as a way to access an immediate source of cash (F. Makete, personal communication, April $5^{\text {th }}, 2011$ ). This source of cash is the 700 pula/ha government subsidy (up to 5 hectares) that farmers who plow for themselves are eligible to receive (instead of using the governmentprovided tractor and labor). Once they have finished plowing and planting however, many of these farmers do not continue to perform the necessary field maintenance (weeding, protecting from pests and domestic or wild animals) that is required to obtain a harvest. For these farmers, she likened plowing to a waged job-farmers plow in order to receive cash from the government and then abandon their fields with little regard for the potential harvest that their fields could yield. ${ }^{32}$ Project research assistants who were village residents confirmed this observation. While the prevalence of this livelihood strategy could not be accurately measured through survey data (due to the sensitivity of the subject), interview data at least suggest the possibility that some farmers in Chobe are plowing their fields in order to gain financially from the state rather than to produce agricultural outputs.

The local agricultural officer also reported that Chobe residents draw on state assistance for agriculture and then abandon their fields after plowing in part because they can then return to the village to seek day wage labor through the village Ipelegeng program. ${ }^{33}$ Naledi residents themselves reported that participation in Ipelegeng reduced the amount of labor available for plowing and maintaining family fields, which in most cases are far away from the village center where Ipelegeng activities take place. ${ }^{34}$ While the agricultural officer was complaining that this behavior means people do not take care of their fields and thus limit their chances of obtaining productive yields, their strategy follows standard economic theory on livelihood decision-making in which households do their best to diversify their livelihood portfolio in order to spread risk and to mobilize all available assets-in this case, physical and financial capital that can be accessed simultaneously through various state channels (i.e. participation in ISPAAD agricultural programs and public work programs) (de Sherbinin et al. 2008). ${ }^{35}$ In this case, state programs appear to work against each other-the presence of Ipelegeng might decrease rural crop production-as households scramble to take advantage of whatever state resources are available to them that can potentially contribute to their livelihood portfolio. ${ }^{36}$

\section{Cultural motivations to continue farming}

Naledi residents plow not only for the strategic reasons described above, but also because plowing one's fields provides a household or individual with a certain degree of cultural capital (Bebbington 1999). In my interviews with residents and with migrants originating from Naledi, I was told repeatedly that

\footnotetext{
${ }^{31}$ A group of women in Naledi hoped to obtain funds for a vegetable garden project through ISPAAD, which provides fencing and assistance to people who cluster their individual fields together in order to encourage larger-scale (supposedly more "efficient") farming. At the time of writing, they had yet to submit a grant so the way they utilize government funds remains to be seen.

32 She contrasted these "less serious" farmers who only receive one benefit-money from ISPAAD—with "serious" farmers who receive two benefits-money from ISPAAD and a harvest of crops that could contribute to household food security and self-sufficiency.

${ }^{33}$ Either choosing to have the state plow for them, or plowing themselves and obtaining monetary reimbursement from the state.

${ }^{34}$ In a follow-up survey in 2012 (by C. Gupta), 36.8 percent of households participating in Ipelegeng stated that participation in Ipelegeng reduced the amount of labor available for farming and another 36.8 percent of househoulds participating in Ipelegeng stated that they had chosen not to plow their fields in the past three years $(\mathrm{N}=19)$. While the sample size makes it difficult to determine if these results are significant, the data at least suggest that Ipelegeng plays a role in causing some farmers to put minimal input into farming (low-level continuation strategy) and that Ipelegeng is in some cases associated with the cessation of farming (abandonment strategy).

${ }^{35}$ While participation in Ipelegeng may not detract from crop production for households without arable land (e.g. 23.4 percent of surveyed Naledi households stated they had neither mopalo nor dryland fields), follow-up research in January 2012 showed that 73.7 percent of households participating in Ipelegeng had either mopalo and/or dryland fields.

${ }^{36}$ While agricultural productivity is minimal at the fields in part because people are drawn to the state resources available in the village, follow-up research in the spring of 2011 (by C. Gupta) suggests that villagers who remain in the village are increasingly planting a variety of crops in their backyard gardens. These gardens have historically been used to plant small amounts of vegetables (usually greens) to serve as "relish," while staple crops such as maize and sorghum are grown in the fields. However some villagers reported using seeds provided by ISPAAD to plant small amounts of staple crops in their backyard, suggesting that agricultural practices are shifting away from the traditional spatial divisions of farming. The degree to which different forms of government support under this emerging scenario are in fact complementary rather than conflicting, as well as the extent and the implications of backyard farming, requires further research.
} 
farming is "our culture," "our lifestyle," or an "African tradition"—an activity that should be continued, despite the challenges. For example, one young man told me that he had interest in raising cattle because he doesn't "want to lose [his] culture." Likewise, another interviewee explained to me that "as you know we are farmers, we grow crops, got cattle, during the day young guys look after cattle, evening we come back." In this way, Naledi residents, many of whom have stopped farming altogether or who farm minimally, emphasize the way in which farming is essential to the Batswana culture and an identifier of a true Motswana. State support has thus prevented the complete disappearance of an agricultural way of life, and allowed the village to retain some semblance of an agricultural livelihood base.

\section{Limited labor and untended fields}

While government assistance may provide Chobe farmers with the incentive to plow their fields and plant crops, some households simply do not have the labor to tend to their fields during the interim period between planting and harvesting. Since independence, seasonal migration between villages and agricultural lands in Botswana has decreased (Gwebu 1987; Silitshena 1983). Today, villagers and local government officials alike report that in Naledi, far fewer farmers stay out at the fields or check on their fields daily during the agricultural season than in the past. The time required for daily travel between the homestead in the village and the fields exacerbates the difficulty of crop husbandry. In my interviews, Naledi villagers gave a number of reasons that together explain the decline in crop husbandry-youth prefer looking for jobs in the village (or nearby town) to staying out at the household agricultural outpost, children who traditionally served as a source of agricultural labor are now in school in the village, residents go to the village on the weekends to drink 'shake-shake' (a local beer) instead of remaining at the fields, and as reiterated to me, in Chobe, farmers see no point in tending to their fields when the chance of substantial crop destruction by elephants despite their best efforts to deter them is perceived to be high. ${ }^{37} \mathrm{~A}$ lack of continuous agricultural labor and wildlife disturbance combined with the availability of agricultural subsidies thus produce the 'low-level continuation' farming strategy of some Chobe residents.

Given this combination of environmental disincentives and government-initiated incentives to farm-farmers who previously had abandoned farming because of wild animal damages are now more likely to take advantage of the free plowing and planting provided through ISPAAD. At the same time, once the government subsidized farming activities (plowing and planting) have ended, these farmers do not necessarily pursue a livelihood strategy of labor-intensive field maintenance given both its opportunity costs (missed opportunities for stable employment elsewhere) and the high risk of failure. This means that agricultural productivity remains low, even if the number of 'farmers' appears to be increasing as indicated by increased numbers of beneficiaries of the ISPAAD program.

\section{Conclusion}

The situation facing farmers in Naledi today represents a case of human-wildlife conflict in the context of a welfare state. The nature of farmer-wildlife relations in Naledi illustrates how human-wildlife conflict can lead to variable and unexpected consequences for smallholder agriculture, depending on the broader political economy and socio-cultural context. It is notable that in Naledi, some villagers maintain the appearances of an agrarian lifestyle - an important cultural marker-through nominal participation in subsidized relatively risk-free agricultural activities (plowing and planting), yet with little expectation of subsistence or cash crop production. Labor constraints and fear of wildlife damage help to explain why farmers may not tend to their fields once they have been plowed. Other farmers do not participate in farming at all and instead rely entirely on non-farm sources of income, in particular government safety net and entitlement programs, as well as remittances. In this way, the Naledi case shows how the political ecology of a region can both mediate the impact of human-wildlife conflict on human welfare and shape the way in which farmers respond to wildlife disturbance.

A political ecological analysis of Chobe highlights the multi-scalar policies (i.e. regarding national development and regional wildlife conservation) and political economic as well as cultural and ecological forces that explain the underlying logic of Naledi residents' livelihood decision-making. In Chobe, conflicting conditions exist for farmers-incentives from the government that encourage farming but ecological conditions (i.e. high elephant populations) resulting from the state's prioritization of wildlife conservation and demographic factors (i.e. outmigration and labor shortages) that make successful agricultural production nearly impossible. The result is that production levels remain low despite farmer participation in agricultural programs.

In terms of policy implications for conservation and development, this analysis questions whether a program like ISPAAD makes sense in a place like Chobe where conditions for farming are so challenging. It suggests the need for region-specific development policies and strategies that are developed to be

\footnotetext{
37 One exemplary story was related to me by an elder man who, in explaining to me why he did not farm anymore, described how despite the fact that his neighbor was keeping his fields in good condition for most of the agricultural season, elephants destroyed his crops towards harvest time so he reaped none of the fruits of his own labor.
} 
appropriate for the local conditions. However, arable agriculture "continues to be a priority in the Chobe district" (DDP 6), despite the recognized problem of land shortage and human-wildlife conflict that has resulted from the zoning of wildlife management areas. While District development plans cite tourism as a means to develop local livelihoods in Chobe, in the past few years the government has at the same time been wary of applications to convert land designated for agricultural use to land designated for tourism purposes. In fact, a recent government directive has ordered Land Board officials to decline applications requesting a transfer of land-use from agriculture to tourism, in order to encourage villagers to continue farming their fields (Tshetlho and Kebaitse, personal communication, April $7^{\text {th }}, 2011$ ).

With increasing elephant disturbance, some policy-makers emphasize the need for farmers to protect their fields and to actively participate in farming activities in between the planting and harvesting period. For example, the Department of Wildlife and National Parks has embarked on a pilot project to introduce chili pepper planting as an elephant deterrent strategy. A local NGO is also experimenting with various agricultural techniques designed to reduce human-wildlife conflict at a demonstration plot just outside the village. But the high cost of such field maintenance combined with a long-standing low input-low output farming approach means that small scale farmers are hesitant to adopt such high-input farming strategies, given that they are rarely able or willing to take on the full-time dangerous job of protecting their crops from wildlife. 38

Residents and local officials alike have also suggested that another possible solution to reduce agriculture-wildlife conflict would be to construct an electrified wildlife fence. However, the government is reluctant to erect fences that might interfere with wildlife migratory routes and that would be difficult to construct given the annual flooding cycles. While few alternate solutions have been posed, in the meantime, agricultural support programs such as ISPAAD and other state support programs such as Ipelegeng appear to be having unexpected effects in regions of high wildlife conflict like Chobe, where farmers are incentivized to plow, yet not necessarily maintain, their fields. Clearly then, state-led development policies do matter and do influence the livelihood decisions that people make-but in ways that reflect the fact that people respond to these policies in conjunction with a suite of other pressing local conditions and realities.

The effects of conservation policy on rural livelihoods are mediated by other state policies at work-a finding that pushes conservation studies towards the development of a more nuanced understanding of how and why the relationship between protected areas (including protected wildlife) and human livelihoods can vary across the globe. As the Naledi case study reveals, the nature of agrarian livelihoods around protected areas in sub-Saharan Africa is variable and complex. Human interactions with wildlife can be best understood through examination of the ways in which a constellation of various political, economic and ecological processes unfold in relation to one another to influence the type of livelihood options available to rural dwellers, their own perceptions of these choices, and the livelihood strategies that they then choose to employ. Answers to the question of how to reconcile rural livelihoods with wildlife conservation will only be found through a site-specific process that begins with such rigorous, critical and multi-stranded analysis.

\section{References}

Barnhoorn, F., R. Jansen, H. T. Riezebos \& J. J. Starkenburg. 1994. Sustainable development in Botswana: an analysis of resource management in three communal development areas. Utrecht: The Royal Dutch Geographic Society and Faculty of Geographical Sciences, Utrecht University.

Bebbington, A. 1999. Capitals and capabilities: a framework for analyzing peasant viability, rural livelihoods and poverty. World Development 27: 2021-2044.

Benza, B. 2008. Botswana strives for food self sufficiency. Mmegionline 25: 165. 7 November. http://www.mmegi.bw/index.php?sid=4\&aid=16\&dir=2008/November/Friday7 (last accessed April 20 2011).

Bernstein, H., B. Crow \& H. Johnson. 1992. Rural livelihoods: crises and responses. Oxford: Oxford University Press.

Bertram, G. 2011. Assessing the structure of small welfare states. United Nations Research Institute for Social Development.

BIDPA. 2001. Consultancy on the review of the rural development policy: final report. Botswana Institute for Development Policy Analysis.

Blaikie, P. \& H. Brookfield. 1987. Land degradation and society. New York: Methuen.

\footnotetext{
${ }^{38}$ Cost here is understood in terms of both opportunity costs of labor time and actual costs of building materials like fencing or irrigation.
} 
Boafo, Y., Dubiure, U.F., Danquah, E.K.A., Manford, M., Nandjui, A., Hema, E.M., Barnes, R.F.W. and B. Bailey 2004. Long-term management of crop raiding by elephants around Kakum Conservation Area in southern Ghana. Pachyderm 19: 37-39.

Botswana Agricultural Marketing Board. 2011. http://www.bamb.co.bw/producer_prices.html. (Retrieved February 2, 2012)

Brockington, D. 2002. Fortress conservation: the preservation of the Mkomazi Game Reserve, Tanzania. Bloomington: University of Indiana Press.

Bryceson, D. 1999. African rural labour, income diversification and livelihood approaches: a long-term development perspective. Review of African Political Economy 26(80): 171-189.

Campbell-Smith, G., Sembiring, R., and M. Linkie. 2012. Evaluating the effectiveness of human-orangutan conflict mitigation strategies in Sumatra. Journal of Applied Ecology. 49: 367-375.

Central Statistics Office. 1987. Maize Production data for Chobe District: 1980-86. Annual Agricultural Statistics, Central Statistics Office.

Central Statistics Office. 2001. Botswana population and housing census. Gaborone: Central Statistics Office.

Central Statistics Office. 2007. Labour Report. Government of Botswana.

Chobe District Council. 2003. Chobe District Development Plan 6: 2003-2009. Government Printer, Gaborone.

Chobe District Council. 2010. Government assistance beneficiaries in Chobe District. Unpublished data.

Davies, T.E., Wilson, S., Hazarika, N., Chakrabarty, J., Das, D., Hodgson, D.J., and A. Zimmerman. 2011. Effectiveness of intervention methods against crop-raiding elephants. Conservation Letters 4(5): 346-354.

Dowie, M. 2009. Conservation refugees: the hundred-year conflict between global conservation and native peoples. Boston: Massachusetts Institute of Technology.

Department of Wildlife and NRMP USAID. 1994. Kachikau Village Community Action Plan.

Department of Agriculture. 2011. Chobe ISPAAD beneficiaries. Unpublished data.

de Sherbinin, A., L. VanWey, K. McSweeney, R. Aggarwal, A. Barbieri, S. Henry, L. Hunter, W. Twine \& R. Walker. 2008. Rural household demographics, livelihoods and the environment. Global Environmental Change 18: 38-53.

Ellis, F. 2000. Rural livelihoods and diversity in developing countries. Oxford: Oxford University Press.

Geisler, C. and R. De Sousa. 2001. From refuge to refugee: the African case. Public Administration and Development 21:159-170.

Granados, A., and R.B. Weladji. 2012. Human-elephant conflict around Benoue National Park, Cameroon: influence on local attitudes and implications for conservation. Human Dimensions of Wildlife 17: 77-90.

Gupta, C. forthcoming. Looking across spatial scales to assess the influence of protected areas on demography and livelihoods in Botswana. (in review)

Gwebu, T. 1987. Internal migration and regional development in Botswana. Regional Institute for Population Studies at the University of Ghana.

Gwebu, T. 2004. Internal migration in Botswana. In: CSO (ed.), Analytical Report of 2001 Population and Housing Census. Gaborone: CSO.

Hartter, J., Goldman, A., and J. Southworth. 2011. Responses by households to resource scarcity and human-wildlife conflict: issues of fortress conservation and the surrounding agricultural landscape. Journal for Nature Conservation 19(2): 79-86.

Hartland-Thunberg, P. 1978. Botswana: an African growth economy. Boulder, Colorado: Westview Press.

Hill, C.M. 2000. Conflict of interest between people and baboons: crop raiding in Uganda. International Journal of Primatology 21(2): 299-315.

Hulme, D. \& M. Murphree. 2001. African wildlife and livelihoods: the promise and performance of community conservation. Oxford: James Currey.

Inskip, C. and A. Zimmermann. 2009. Human-felid conflict: a review of patterns and priorities worldwide. Oryx 43(1): 18-34.

Jones, D. 1981. Arable agriculture in Botswana: a case for subsidies. In Harvey C. (ed.) Papers on the economy of Botswana. London: Heinemann.

Kemmonye, M. 2009. Chobe District profile. Kasane: Rural Administration Center.

Leechor, C. 2005. Developing tourism in Botswana: progress and challenges. World Bank.

Lesetedi, G.N. 2003. Urban-rural linkages as an urban survival strategy among urban dwellers in Botswana: the case of Broadhurst residents. Journal of Political Ecology 10: 37-46.

Li, T.M. 2007. The will to improve. Raleigh/Durham: Duke University Press. 
MacDonald, M. 1989. Prefeasibility study of the agricultural potential of the Chobe enclave: final report. Gaborone: Sir M. MacDonald and Partners; Ministry of Agriculture, Government of Botswana.

Mackenzie, C.A. and P. Ahabyona. 2012. Elephants in the garden: financial and social costs of crop raiding. Ecological Economics 75: 72-82.

Ministry of Environment, Wildlife and Tourism. 2007. Community based natural resources management policy. Botswana Government Printer.

Naughton-Treves, L., Treves, A., Chapman, C., and R. Wrangham.1998. Temporal patterns of crop-raiding by primates: linking food availability in croplands and adjacent forest. Journal of Applied Ecology 35: 596-606.

Neumann, R. 1998. Imposing wilderness: struggles over livelihood and nature preservation in Africa. Berkeley: University of California Press.

Ngeta, K. 2011. Wildlife conservation and land acquisitions: a case study of the Tanzania Land Conservation Trust. In International Conference on Global Land Grabbing. University of Sussex.

Quirin, C. and A. Dixon. 2012. Food security, politics and perceptions of wildlife damage in Western Ethiopia. International Journal of Pest Management 58(2): 37-41.

Polet, G. 1988. Unpublished survey data. In MacDonald, M. 1989. Prefeasibility study of the agricultural potential of the Chobe Enclave: final report. Gaborone: Sir M. MacDonald and Partners; Ministry of Agriculture, Government of Botswana.

Robbins, P. 2004. Political ecology: a critical introduction. $1^{\text {st }}$ edition. Malden, MA: Blackwell Publishing.

Rozemeijer, N. 2009. CBNRM in Botswana. In H. Suich, B. Child \& A. Spenceley (eds.) Evolution and innovation in wildlife conservation: parks and game ranches to transfrontier conservation areas. London: Earthscan.

Schapera, I. 1966. Married life in an African tribe. Evanston: Northwestern University Press.

Schmidt-Soltau, K. 2003. Conservation-related resettlement in central Africa: environmental and social risks. Development and Change 34: 525-551.

Seleka, T. 2004. Diversification in Botswana's agricultural sector: issues, prospects and challenges. In BIDPA Publication Series. Botswana Institute for Development and Policy Analysis. Gaborone: BIDPA.

Seleka, T., H. Siphambe, D. Ntseane, N. Mbere, C. Kerapeletswe and C. Sharp. 2007. Social safety nets in Botswana: administration, targetting and sustainability. Gaborone: Botswana Institute for Development Policy Analysis.

SIAPAC. 1992. Baseline survey of the Chobe Enclave final report. Gaborone: Department of Wildlife and National Parks.

Silitshena, R. 1993. Where will Batswana live in the 21st century? Patterns of settlement and migration. In Botswana in the 21st Century, proceedings of a symposium. Gabarone: the Botswana Society.

Sitati N.W. 2003. Human-elephant conflict in Transmara District adjacent to Masai Mara National Reserve, Kenya. PhD thesis. Canterbury, U.K.: University of Kent.

Sitati N.W., Walpole M.J., Smith R.J., and N. Leader-Williams. 2003. Predicting spatial aspects of humanelephant conflict. Journal of Applied Ecology 40: 667-677.

Tsimako, B. 1984. A baseline socio-economic study of the Chobe Enclave. Gaborone: Rural Sociology Unit, Division of Planning and Statistics, Ministry of Agriculture.

USAID. 2003. The Chobe enclave land use and management plan. USAID and African Wildlife Foundation.

The Voice. 2008. Botswana: tourism contributes 16 percent to GDP. Francistown. http://allafrica.com/stories/200803110721.html (Retrieved February 25, 2012)

Walker, K.L. 2012. Labor costs and crop protection from wildlife predation: the case of elephants in Gabon. Agricultural Economics 43: 61-73.

Watts, M.J. 1983. Silent violence: food, famine and peasantry in northern Nigeria. Berkeley: University of California Press.

West P., Igoe J., and D. Brockington, D. 2006. Parks and peoples: the social impact of protected areas. Annual Review of Anthropology 35: 251-277.

World Bank. 2009. Project appraisal document on a proposed grant to the Republic of Botswana for a Northern Botswana Human Wildlife Coexistence Project. Washington D.C.: The World Bank. Cached version. 


\begin{abstract}
Resolving conflict between agricultural livelihoods and wildlife conservation requires a sophisticated understanding of both wildlife ecology and human livelihood decision-making. This case study extends the literature on human-wildlife conflict in Africa by using a political ecology framework to understand how and why farmers in areas of high wildlife disturbance make their farming decisions, and how their strategies are affected by a broader socio-political context that includes, but is not restricted to, wildlife conservation policy. Specifically, this article chronicles the livelihood strategies of smallholder farmers in a village on the edge of Chobe National Park in northern Botswana. This is a place where the state has prioritized wildlife conservation but also supports residents' livelihoods. Because of disturbance from wildlife, especially elephants, protected under conservation law, agricultural production in Chobe is becoming increasingly challenging, even as the government increases its agricultural subsidies and support to small farmers. This results in unexpected farming strategies that reflect the interactive effects of conservation policy and other relevant macro-economic policies that structure the livelihood strategies of rural communities living near protected areas. Future human-wildlife conflict studies must take into account these multi-scalar and multi-dimensional dynamics in order to accurately explain the livelihood strategies of people living in wildlife-populated areas, so that appropriate conservation and development policies can be designed.
\end{abstract}

Keywords: Botswana, wildlife conservation, rural livelihoods, human-wildlife conflict, political ecology

\title{
Résumé
}

La résolution des conflits entre l'agriculture de subsistance et la conservation de la faune exige une connaissance approfondie de l'écologie de la faune et de la prise de décision. Cette étude de cas s'étend la littérature sur les conflits humains-faune en Afrique en utilisant un cadre de l'écologie politique à comprendre comment et pourquoi les agriculteurs des zones de perturbation forte de la faune prennent leurs décisions agricoles, et comment leurs stratégies sont touchés par un contexte socio-politique plus large qui inclut, mais n'est pas limité à, la politique de conservation de la faune. Plus précisément, cet article raconte les stratégies de subsistance des petits exploitants dans un village sur le bord du parc national de Chobe, dans le nord du Botswana. C'est un endroit où l'Etat a privilégié la conservation de la faune, mais aussi soutient les moyens d'existence des habitants. À cause de la perturbation de la faune sauvage, en particulier les éléphants, protégées par la loi de la conservation, la production agricole en Chobe est de plus plus en plus exigeant, alors même que le gouvernement augmente ses des subventions agricoles et le soutien aux petits agriculteurs. Cela se traduit par des stratégies d'agriculture inattendus qui reflètent les effets interactifs de la politique de conservation et d'autres politiques macro-économiques pertinents qui structurent les stratégies de subsistance des communautés rurales vivant à proximité des zones protégées. Études sur les conflits homme-faune sauvage dans l'avenir doit tenir compte de cette dynamique (multiscalaire et multi-dimensionnelle) afin d'expliquer précisément les stratégies de subsistance des personnes vivant dans des zones peuplées par la faune. Cela permettra à la conception des politiques de conservation et de développement approprié.

Mots-clés: Botswana, conservation de faune, les moyens de subsistance en milieu rural, les conflits homme-faune, l'écologie politique

\section{Resumen}

Resolver el conflicto entre formas de vida agrícola y la conservación de la vida silvestre requiere de un conocimiento tanto de la ecología de la fauna y flora así como los procesos de toma de decisiones de la gente sobre su bienestar. Este estudio de caso aporta a la literatura sobre el conflicto entre humanos y vida silvestre en África al utilizar una perspectiva de ecología política para entender cómo y porque granjeros en el norte de Botswana toman sus decisiones respeto a la agricultura en áreas de alto impacto a la vida silvestre, y como sus estrategias son afectadas por un contexto socio-político más amplio que incluye, pero no está restringido, a políticas de conservación. Este es un lugar donde el Estado ha priorizado la conservación de la vida silvestre pero también apoya las formas de vida de sus habitantes. Debido a los daños ocasionados por elefantes protegidos bajo la ley de conservación, la producción agrícola en Chobe se ha vuelto especialmente difícil, aun cuando el gobierno ha incrementado los subsidios agricolas y los apoyos a los pequeños agricultores. Esto ha resultado en estrategias agrícolas inesperadas que reflejan los efectos interactivos de las políticas de conservación y otras políticas macro-económicas que estructuran las estrategias de supervivencia de comunidades rurales ubicadas cerca de áreas protegidas. Estudios futuros sobre el conflicto entre humanos y vida salvaje deben tomar en cuenta las dinámicas de escala múltiples y multidimensionales para poder explicar adecuadamente las estrategias de sobrevivencia de l agente que vive en áreas con vida salvaje, para que se puedan diseñar políticas de desarrollo y conservación apropiadas.

Palabras clave: Botswana, conservación de la vida silvestre, vida rural, conflicto humanos-vida salvaje, ecología política. 